\title{
Epidemiology of Ischæmic Heart Disease in India with Special Reference to Causation
}

\author{
S. L. MALHOTRA
}

\author{
From the Medical Department, Western Railway, Bombay, India
}

Because of important geographical differences in its prevalence, not only between different countries but even within a single country, ischæmic heart disease is thought to be due to the interplay of many factors, most of which are environmental. The dietary trend is one and the decline of physical activity is another, each of which is believed to play a major role. Several other factors, such as smoking (Doll and Hill, 1956), stress (Hammarsten et al., 1957), and softness or hardness of water (Schroeder, 1960) have also been incriminated.

The study reported in this paper was undertaken (a) to determine the geographical distribution of the disease in railway populations in various parts of India, and (b) to define the role of the causal influences mentioned above.

\section{SubJECTS AND METHODS}

Population at Risk. The study concerns $1 \cdot 15$ million railway workers between the ages of 18-55 years serving on the 8 zonal railways in different parts of India. The period studied was from January 1, 1958, to December 31,1962 . The size of the population on each zone has been obtained by averaging the number of railway employees on the pay-rolls during this 5 -year period (total for 5 years divided by 5 ). Wives and children have been excluded from this, because first their number is less precisely known and secondly there are no cases among them in this series. Because of the uniform administrative patterns of recruitment, promotions, superannuation, and staffing, the age and sex structure of the railway employees, as well as their socio-economic distribution, are by and large comparable in the different zones. The only exception is the top executive, as they are borne on an all-India cadre and their placement on a particular railway zone is, therefore, purely fortuitous; nor is their age structure in different zones comparable, for the same reason.

It must, however, be emphasized that ours is a highly selected population of Government servants working on

Received November 28, 1966. the railways limited only to the age-group 18-55 years, and this study, therefore, cannot claim to represent the experience in the general population in the country. Its aim chiefly is to study the geographical aspects of the disease in railway populations of comparable constitutions in various parts of the country.

The hospital services for railway employees are provided almost exclusively by the group of 88 railway hospitals and their associated units, distributed throughout the country and run by the Ministry of Railways for the exclusive benefit of the railway staff. The services provided are comprehensive, free of charge, cover all specialities, and include the "dependent" family members.

\section{METHOD OF INVESTIGATION}

In 1963 the Ministry of Railways carried out a survey with a view to ascertaining the number of deaths due to ischæmic heart disease among railway populations in different parts of the country. The method employed was to obtain data from all the railway zones on a proforma based on W.H.O. classification 420, for arteriosclerotic, including coronary heart disease. This ascertainment of deaths was done by the different units, by a search of individual hospital records and electrocardiograms, and matching these with mortality returns of the units concerned. An independent means of checking the degree of ascertainment was the death certificate books in which disease as named in W.H.O. international statistical classification is mentioned. The study reported in this paper stems from an attempt to analyse the data obtained by the survey.

A total of 720 deaths was admitted in the provisional list and as a result of the re-examination of the data, 34 were rejected for lack of full details or because another diagnosis seemed more likely. Seven deaths were amongst women and these have been excluded. The geographical distribution of the remaining 679 deaths among men, proved electrocardiographically to be due to ischæmic heart disease, is displayed in Table I, and their further analysis, socio-economically, and on the basis of physical activity at work, in Tables II and III. Of these 679 deaths, 139 had concomitant hypertension, 895 
TABLE I

FIVE-YEAR MORTALITY FROM ARTERIOSCLEROTIC AND CORONARY HEART DISEASE ON VARIOUS INDIAN ZONAL RAILWAYS DURING 1958-1962 BASED ON THE TOTAL NUMBER OF EMPLOYEES ON PAY-ROLLS

\begin{tabular}{|c|c|c|c|c|c|}
\hline Railway zones & $\begin{array}{l}\text { No. of } \\
\text { deaths }\end{array}$ & $\begin{array}{l}\text { Total no. of } \\
\text { employees } \\
(18-55 \text { years })\end{array}$ & $\begin{array}{l}\text { Mortality rate } \\
\text { per } 100,000 \\
\text { employees during } \\
\text { quinquennium }\end{array}$ & $\begin{array}{l}\text { Total in-patient } \\
\text { admissions for } \\
\text { all diseases }\end{array}$ & $\begin{array}{l}\text { Percentage of } \\
\text { deaths to } \\
\text { total admissions }\end{array}$ \\
\hline $\begin{array}{l}\text { Northern } \\
\text { Western } \\
\text { North-eastern } \\
\text { Eastern } \\
\text { North-east frontier } \\
\text { Central } \\
\text { South-eastern } \\
\text { Southern }\end{array}$ & $\begin{array}{r}36 \\
41 \\
28 \\
88 \\
36 \\
126 \\
105 \\
219\end{array}$ & $\begin{array}{r}178,311 \\
162,264 \\
84,964 \\
176,633 \\
63,120 \\
200,308 \\
123,497 \\
161,719\end{array}$ & $\begin{array}{r}20 \\
25 \\
33 \\
50 \\
57 \\
63 \\
85 \\
135\end{array}$ & $\begin{array}{l}23,313 \\
17,771 \\
27,148 \\
43,027 \\
12,330 \\
25,504 \\
15,660 \\
28,528\end{array}$ & $\begin{array}{l}0.15 \\
0.23 \\
0.10 \\
0.20 \\
0.29 \\
0.49 \\
0.67 \\
0.77\end{array}$ \\
\hline Total & 679 & $1,150,816$ & 59 & 193,281 & 0.35 \\
\hline
\end{tabular}

TABLE IA

AGE DISTRIBUTION OF DEATHS IN VARIOUS RAILWAY ZONES

\begin{tabular}{|c|c|c|c|c|c|c|c|c|c|c|c|c|c|c|c|c|}
\hline \multirow{3}{*}{$\begin{array}{l}\text { Age (yr.) } \\
\\
<30 \\
31-35 \\
36-40 \\
41-45 \\
46-50 \\
51-55\end{array}$} & \multicolumn{16}{|c|}{ Railway zones } \\
\hline & \multicolumn{2}{|c|}{ Northern } & \multicolumn{2}{|c|}{ Western } & \multicolumn{2}{|c|}{$\begin{array}{l}\text { North- } \\
\text { eastern }\end{array}$} & \multicolumn{2}{|c|}{ Eastern } & \multicolumn{2}{|c|}{$\begin{array}{l}\text { North-east } \\
\text { frontier }\end{array}$} & \multicolumn{2}{|c|}{ Central } & \multicolumn{2}{|c|}{$\begin{array}{l}\text { South- } \\
\text { eastern }\end{array}$} & \multicolumn{2}{|c|}{ Southern } \\
\hline & $\begin{array}{r}1 \\
1 \\
5 \\
9 \\
5 \\
15\end{array}$ & $\begin{array}{c}(3 \%) \\
(3 \%) \\
(14 \%) \\
(25 \%) \\
(14 \%) \\
(41 \%)\end{array}$ & $\begin{array}{r}0 \\
1 \\
5 \\
9 \\
8 \\
18\end{array}$ & $\begin{array}{c}(0 \%) \\
(2 \%) \\
(12 \%) \\
(22 \%) \\
(20 \%) \\
(44 \%)\end{array}$ & $\begin{array}{l}2 \\
5 \\
8 \\
7 \\
3 \\
3\end{array}$ & $\begin{array}{l}(7 \%) \\
(18 \%) \\
(28 \%) \\
(25 \%) \\
(11 \%) \\
(11 \%)\end{array}$ & $\begin{array}{r}9 \\
7 \\
11 \\
18 \\
20 \\
23\end{array}$ & $\begin{array}{c}(10 \%) \\
(8 \%) \\
(13 \%) \\
(20 \%) \\
(23 \%) \\
(26 \%)\end{array}$ & $\begin{array}{r}2 \\
1 \\
9 \\
8 \\
5 \\
11\end{array}$ & $\begin{array}{c}(6 \%) \\
(3 \%) \\
(25 \%) \\
(22 \%) \\
(14 \%) \\
(30 \%)\end{array}$ & $\begin{array}{r}12 \\
8 \\
21 \\
23 \\
21 \\
41\end{array}$ & $\begin{array}{c}(9 \%) \\
(6 \%) \\
(17 \%) \\
(18 \%) \\
(17 \%) \\
(33 \%)\end{array}$ & $\begin{array}{r}8 \\
5 \\
24 \\
22 \\
27 \\
19\end{array}$ & $\begin{array}{c}(7 \%) \\
(5 \%) \\
(23 \%) \\
(21 \%) \\
(26 \%) \\
(18 \%)\end{array}$ & $\begin{array}{r}9 \\
20 \\
40 \\
38 \\
38 \\
74\end{array}$ & $\begin{array}{l}(4 \%) \\
(9 \%) \\
(18 \%) \\
(17.5 \%) \\
(17.5 \%) \\
(34 \%)\end{array}$ \\
\hline Total & 36 & & 41 & & 28 & & 88 & & 36 & & 126 & & 105 & & 219 & \\
\hline Mean age at death & 52 & & 50 & & 42 & & 45 & & 43 & & 44 & & 40 & & 44 & \\
\hline
\end{tabular}

Dietary factors. The data on the patterns of diets, methods of cooking, and eating were obtained (a) from interview directly of a number of railwaymen and their wives in different geographical areas; (b) from several roadside eating houses in different parts of the country, which reflect the regional eating habits and patterns of diet, and (c) from official diet surveys (Indian Council of Medical Research, 1953, 1964).

Softness or hardness of water. Data on softness or hardness of water were obtained from the locomotive departments of various zonal railways which invariably maintain these data, as hard water is unfit for locomotive use and has to be softened.

Stress. Stress cannot be readily measured and different people react differently to the same situation or stimulus. The parameter used in this study, though of limited value, is the total number of disciplinary action cases for service lapses on the zonal railways, which had large differences in the incidence of the disease (Table IV). Unfortunately, due to certain technical difficulties,

TABLE II

DISTRIBUTION OF DEATHS AND COMPARATIVE MORTALITY RATES IN THREE OCCUPATIONAL CLASSES SHOWING VARYING PHYSICAL ACTIVITY AT WORK

\begin{tabular}{|c|c|c|c|c|c|c|c|c|c|c|c|}
\hline \multirow{2}{*}{ Railway zones } & \multicolumn{3}{|c|}{ Fitters $(£ 96-£ 180)$} & \multicolumn{4}{|c|}{ Clerks $(£ 156-£ 516)$} & \multicolumn{4}{|c|}{ Sweepers $(£ 60-£ 72)$} \\
\hline & $\begin{array}{c}\text { No. at } \\
\text { risk }\end{array}$ & $\begin{array}{l}\text { No. of } \\
\text { deaths }\end{array}$ & $\begin{array}{c}\text { Deaths per } \\
100,000\end{array}$ & $\begin{array}{l}\text { No. at } \\
\text { risk }\end{array}$ & $\begin{array}{l}\text { No. of } \\
\text { deaths }\end{array}$ & $\begin{array}{l}\text { Dea } \\
100\end{array}$ & $\begin{array}{l}\text { hs per } \\
000\end{array}$ & ${ }_{\text {risk }}^{\text {No. at }}$ & $\begin{array}{l}\text { No. of } \\
\text { deaths }\end{array}$ & $\begin{array}{r}\text { Deatl } \\
100\end{array}$ & $\begin{array}{l}\text { as per } \\
000\end{array}$ \\
\hline $\begin{array}{l}\text { Northern } \\
\text { North-eastern } \\
\text { Western } \\
\text { Eastern } \\
\text { North-east frontier } \\
\text { Central } \\
\text { South-eastern } \\
\text { Southern } \\
\end{array}$ & $\begin{aligned} 7102 \\
4814 \\
10,272 \\
12,076 \\
2624 \\
10,808 \\
5648 \\
10,398 \\
\end{aligned}$ & $\begin{array}{r}7 \\
4 \\
5 \\
14 \\
2 \\
12 \\
6 \\
18\end{array}$ & $\begin{aligned} 99 & (46) \\
83 & (47) \\
49 & (45) \\
116 & (40) \\
76 & (53) \\
111 & (45) \\
106 & (45) \\
173 & (41)\end{aligned}$ & \begin{tabular}{r|}
11,983 \\
8081 \\
8509 \\
13,498 \\
8072 \\
12,982 \\
16,908 \\
12,090
\end{tabular} & $\begin{array}{r}7 \\
2 \\
3 \\
3 \\
3 \\
12 \\
8 \\
19\end{array}$ & $\begin{array}{r}58 \\
25 \\
35 \\
22 \\
37 \\
92 \\
47 \\
157\end{array}$ & $\begin{array}{l}(47) \\
(31) \\
(46) \\
(45) \\
(53) \\
(40) \\
(47) \\
(44)\end{array}$ & $\begin{array}{l}7702 \\
3186 \\
5258 \\
5681 \\
3663 \\
3179 \\
4047 \\
4055\end{array}$ & $\begin{array}{l}1 \\
2 \\
5 \\
2 \\
2 \\
7 \\
7 \\
8\end{array}$ & $\begin{array}{r}13 \\
62 \\
95 \\
35 \\
55 \\
220 \\
173 \\
197\end{array}$ & $\begin{array}{l}(49) \\
(35) \\
(45) \\
(50) \\
(47) \\
(55) \\
(41) \\
(39)\end{array}$ \\
\hline Total & 63,792 & 68 & $106 \cdot 6 \quad(45)$ & 92,123 & 57 & $61 \cdot 8$ & (44) & 36,771 & 34 & 92.4 & (44) \\
\hline
\end{tabular}

Figures in parentheses indicate the mean age at death. 
TABLE III

DISTRIBUTION OF DEATHS AND MORTALITY RATES IN SOCIO-ECONOMIC CLASSES ON VARIOUS ZONAL RAILWAYS

\begin{tabular}{|c|c|c|c|c|c|c|c|c|c|c|}
\hline \multirow{2}{*}{ Railway zones } & \multicolumn{3}{|c|}{$\begin{array}{c}\text { Classes I and II (executives) } \\
(£ 800-3000 \text { p.a. })\end{array}$} & \multicolumn{3}{|c|}{$\begin{array}{c}\text { Class III } \\
(£ 100-£ 500 \text { p.a. })\end{array}$} & \multicolumn{3}{|c|}{$\begin{array}{c}\text { Class IV } \\
(£ 60-£ 70 \text { p.a. })\end{array}$} & \multirow{2}{*}{$\begin{array}{l}\text { Total } \\
\text { deaths }\end{array}$} \\
\hline & $\begin{array}{l}\text { No. at } \\
\text { risk }\end{array}$ & Deaths & $\begin{array}{c}\text { Mor- } \\
\text { tality per } \\
100,000\end{array}$ & $\begin{array}{l}\text { No. at } \\
\text { risk }\end{array}$ & Deaths & $\mid \begin{array}{c}\text { Mor- } \\
\text { tality per } \\
100,000\end{array}$ & $\begin{array}{l}\text { No. at } \\
\text { risk }\end{array}$ & Deaths & $\left|\begin{array}{c}\text { Mor- } \\
\text { tality per } \\
100,000\end{array}\right|$ & \\
\hline $\begin{array}{l}\text { Northern } \\
\text { North-eastern } \\
\text { Western } \\
\text { Eastern } \\
\text { North-east frontier } \\
\text { Central } \\
\text { South-eastern } \\
\text { Southern }\end{array}$ & $\begin{array}{l}659 \\
525 \\
560 \\
525 \\
331 \\
567 \\
526 \\
546\end{array}$ & $\begin{array}{l}1 \\
0 \\
3 \\
1 \\
0 \\
4 \\
4 \\
2\end{array}$ & $\begin{array}{r}152 \\
0 \\
536 \\
190 \\
0 \\
705 \\
760 \\
366\end{array}$ & $\begin{array}{l}66,421 \\
33,227 \\
65,806 \\
76,846 \\
24,408 \\
71,850 \\
52,300 \\
66,580\end{array}$ & $\begin{array}{l}26 \\
15 \\
18 \\
52 \\
22 \\
56 \\
38 \\
96\end{array}$ & $\begin{array}{r}39 \\
45 \\
27 \\
67 \\
90 \\
78 \\
72 \\
144\end{array}$ & $\begin{array}{r}11,231 \\
51,212 \\
95,898 \\
99,262 \\
38,381 \\
127,891 \\
70,671 \\
94,953\end{array}$ & $\begin{array}{r}9 \\
13 \\
20 \\
35 \\
14 \\
66 \\
63 \\
121\end{array}$ & $\begin{array}{r}8 \\
25 \\
21 \\
35 \\
36 \\
52 \\
89 \\
127\end{array}$ & $\begin{array}{r}36 \\
28 \\
41 \\
88 \\
36 \\
126 \\
105 \\
219\end{array}$ \\
\hline Total & 4239 & 15 & 354 & 457,438 & 323 & 71 & 689,499 & 341 & 49 & 679 \\
\hline Mean age at death & & 52 & & & 45 & & & 42 & & \\
\hline
\end{tabular}

TABLE IIIA

DISTRIBUTION OF DEATHS BY AGE IN SOCIO-ECONOMIC CLASSES, ON VARIOUS ZONAL RAILWAYS

\begin{tabular}{|c|c|c|c|c|c|c|c|c|c|c|c|c|c|c|c|c|c|c|c|c|c|c|c|c|}
\hline \multirow{2}{*}{ Age (yr.) } & \multicolumn{3}{|c|}{ Northern } & \multicolumn{3}{|c|}{$\begin{array}{l}\text { North- } \\
\text { eastern }\end{array}$} & \multicolumn{3}{|c|}{ Western } & \multicolumn{3}{|c|}{ Eastern } & \multicolumn{3}{|c|}{$\begin{array}{l}\text { North-east } \\
\text { frontier }\end{array}$} & \multicolumn{3}{|c|}{ Central } & \multicolumn{3}{|c|}{$\begin{array}{l}\text { South- } \\
\text { eastern }\end{array}$} & \multicolumn{3}{|c|}{ Southern } \\
\hline & A & B & C & A & B & C & A & B & $\mathrm{C}$ & A & B & C & $\mathbf{A}$ & B & C & A & B & C & A & B & C & A & B & C \\
\hline $\begin{array}{l}<30 \\
31-35 \\
36-40 \\
41-45 \\
46-50 \\
51-55\end{array}$ & $\begin{array}{l}0 \\
0 \\
0 \\
0 \\
0 \\
1\end{array}$ & $\begin{array}{r}1 \\
0 \\
4 \\
5 \\
6 \\
10\end{array}$ & $\begin{array}{l}1 \\
0 \\
1 \\
3 \\
2 \\
2\end{array}$ & $\begin{array}{l}0 \\
0 \\
0 \\
0 \\
0 \\
0\end{array}$ & $\begin{array}{l}1 \\
4 \\
5 \\
1 \\
3 \\
1\end{array}$ & $\begin{array}{l}1 \\
4 \\
0 \\
6 \\
1 \\
1\end{array}$ & $\begin{array}{l}0 \\
0 \\
0 \\
1 \\
0 \\
2\end{array}$ & $\begin{array}{r}0 \\
0 \\
2 \\
3 \\
2 \\
11\end{array}$ & $\begin{array}{l}2 \\
2 \\
6 \\
4 \\
4 \\
2\end{array}$ & $\begin{array}{l}0 \\
0 \\
0 \\
0 \\
0 \\
1\end{array}$ & $\begin{array}{r}6 \\
6 \\
4 \\
11 \\
15 \\
10\end{array}$ & $\begin{array}{r}4 \\
2 \\
9 \\
6 \\
10 \\
4\end{array}$ & $\begin{array}{l}0 \\
0 \\
0 \\
0 \\
0 \\
0\end{array}$ & $\begin{array}{l}2 \\
0 \\
5 \\
6 \\
4 \\
5\end{array}$ & $\begin{array}{l}0 \\
0 \\
5 \\
3 \\
4 \\
2\end{array}$ & $\begin{array}{l}0 \\
0 \\
0 \\
0 \\
3 \\
1\end{array}$ & $\begin{array}{r}0 \\
3 \\
7 \\
12 \\
11 \\
23\end{array}$ & $\begin{array}{r}10 \\
6 \\
9 \\
17 \\
12 \\
12\end{array}$ & $\begin{array}{l}0 \\
0 \\
0 \\
1 \\
0 \\
3\end{array}$ & $\begin{array}{r}1 \\
0 \\
7 \\
7 \\
9 \\
14\end{array}$ & $\begin{array}{r}8 \\
6 \\
18 \\
16 \\
11 \\
4\end{array}$ & $\begin{array}{l}0 \\
0 \\
0 \\
0 \\
0 \\
2\end{array}$ & $\begin{array}{r}6 \\
13 \\
13 \\
15 \\
16 \\
33\end{array}$ & $\begin{array}{r}5 \\
14 \\
23 \\
27 \\
17 \\
35\end{array}$ \\
\hline $\begin{array}{l}\text { Total } \\
\text { Mean age at } \\
\text { death }\end{array}$ & $\begin{array}{r}1 \\
53\end{array}$ & $\begin{array}{l}26 \\
48\end{array}$ & $\begin{array}{r}9 \\
45\end{array}$ & 0 & 15 & $\begin{array}{l}13 \\
41\end{array}$ & $\begin{array}{r}3 \\
53\end{array}$ & 50 & $\begin{array}{l}20 \\
42\end{array}$ & 53 & 52 & 35 & 0 & 22 & 14 & 50 & 56 & 66 & 51 & 38 & 63 & 53 & 96 & 121 \\
\hline
\end{tabular}

$A=$ Executives $(£ 800-£ 3000)$.

$\mathbf{B}=$ Class III employees $(£ 100-£, 500)$

$\mathrm{C}=$ Class IV employees $(£ 60-£ 70)$.

this information was not available from all the zonal railways.

Smoking. Data on smoking are based on the sale of cigarettes, obtained from trade sources. Their value is limited because the figures reflect the regional smoking habits but not necessarily the objective smoking habits of the railway populations. Since, however, the railway populations are derived from the regional populations, we have assumed that these data would also apply to our material in a broader sense for purposes of group comparisons within the railway populations.

Physical activity. The parameter used is the same as in the paper of Morris et al. (1953), and only three trades, namely clerks, fitters, and sweepers, have been studied because the age distribution of the population at risk in these is not affected by promotion or transfer to other trades.

\section{RESULTS}

The 5-year mortality expressed per 100,000 of railway employees is set out in Table I and shows that big geographical differences exist in different parts of the country (a map of India is shown at Fig. 1). The highest mortality was in the southern zone $(135$ per 100,000$)$ in the south of India, and the lowest in the northern, western, and northeastern zones $(20,25$, and 33 per 100,000 respectively), i.e. the north of India.

TABLE IV

MORTALITY VERSUS DISCIPLINARY ACTIONS

\begin{tabular}{l|c|c|c}
\hline $\begin{array}{c}\text { Railway } \\
\text { zones }\end{array}$ & $\begin{array}{c}\text { No. of charge- } \\
\text { sheets for } \\
\text { removal from } \\
\text { service during } \\
1962\end{array}$ & $\begin{array}{c}\text { Charge-sheets } \\
\text { per } 1000 \\
\text { employees } \\
\text { per annum }\end{array}$ & $\begin{array}{c}\text { Mortality per } \\
100,000 \\
\text { employees }\end{array}$ \\
\hline $\begin{array}{l}\text { Northern } \\
\text { Western }\end{array}$ & 1038 & $5 \cdot 83$ & 20 \\
Southern & 3307 & $20 \cdot 38$ & 25 \\
Eastern & 5306 & $32 \cdot 87$ & 135 \\
\hline
\end{tabular}

* This information is incomplete and pertains only to 2 divisions of Eastern Railway out of total of 5 divisions. 


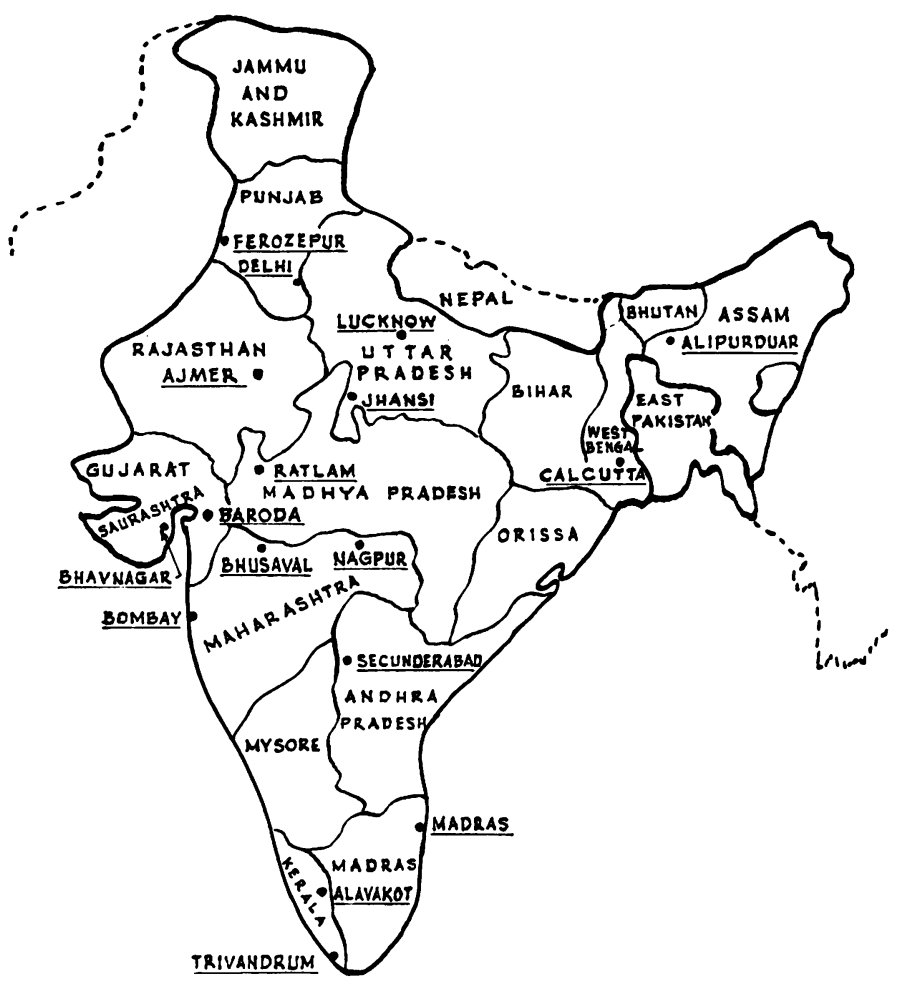

FIG. 1.-Diagrammatic map of India.

Age and Sex. The average age at death was lower amongst the south Indians of the southern railway as compared with the Punjabis of the northern railway, the respective figures being 44 years and 52 years (Table IA). This is also corroborated by the independent data of the mortality experience of the south Indians versus the north Indians on the central and south-eastern zones, both of which serve the south in addition to the northern and/or the eastern parts of the country, respectively, and, therefore, provide an independent source of information.

Mortality was extremely low in women, there being only 7 deaths in this series; 2 of these women were from the south and were above 50 years of age and themselves employed, and the other 5, all with high blood pressure, were widowed mothers of railway employees, past menopause, ranging in age from $60-72$ years.

Socio-economic Gradient and Sedentary Versus Physically Active Occupations. Mortality in the higher socio-economic group of executives (annual income $£ 850-3000$ ) was nearly 7 times more compared with the lower socio-economic class IV (annual income $£^{60-70)}$ as seen from the data in Table III.

Deaths in the sedentary occupations of clerks and the two physically active occupations, one in a lower socio-economic group (sweepers) and the other in a higher socio-economic group (fitters), are displayed in Table II. The mortality was lower in the sedentary occupation of clerks as compared with the physically active occupations of fitters and sweepers.

Diet. Differences in dietary habits exist not only between different parts of the country but even within the same region, between different socioeconomic groups, and an account of some aspects of this has been published elsewhere (Malhotra, $1964 ; 1967 a)$. Fig. 2 summarizes the data on diet surveys (Indian Council of Medical Research, 1964) for Madras and the Punjab. The consumption of fats is 8-19 times higher in the Punjab (north India) as compared with Madras in the south (Indian Council of Medical Research, 1964). Similarly the consumption of sugar is much higher in the north than in the south (Fig. 2), being $90 \mathrm{~g}$. per person per day in the Punjab in contrast to $10 \mathrm{~g}$. per person per day in the south (Indian Council of Medical Research, 1964). 


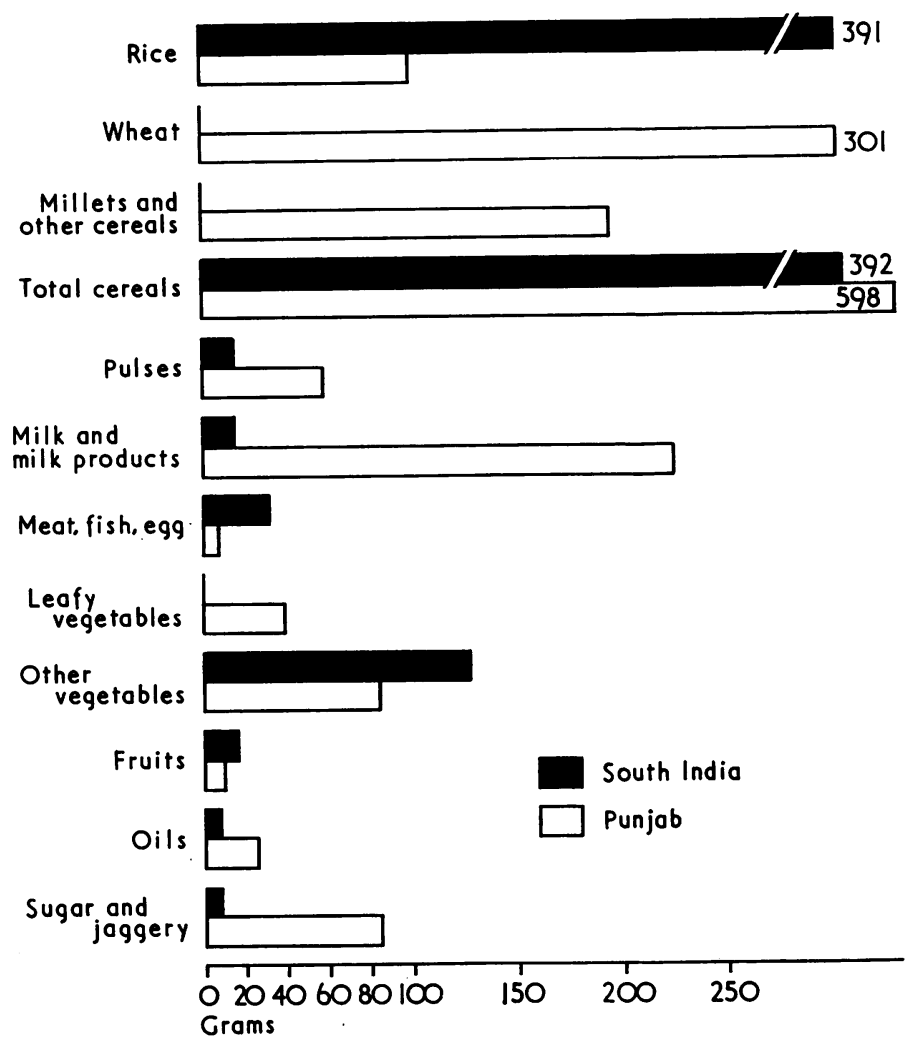

Fig. 2.-Food consumption pattern in south India and the Punjab. (From Diet Atlas of India, Indian Coun. med. Res. Sp. Rep. Ser. No. 48)

\section{Questions of Bias in Methods}

Deaths. In a study using the retrospective approach a number of criticisms arise. The accuracy of data from several different hospitals and in which different physicians were concerned must suffer from the defect of varying competence in diagnosis. Although this may have influenced the accuracy of the total frequency recorded, it is unlikely to have affected the geographical variations. On the contrary, the large number of physicians concerned introduces a random element which, in the absence of a single uniform opinion, is the best safeguard against bias in any one group. Furthermore, in this study, the original data fortunately pertained to deaths where the diagnosis is usually less in doubt, especially if death takes place in a hospital. Doubt about sudden deaths and deaths not taking place in a hospital must remain a genuine point; and, while a number of such unknown deaths must have produced underestimates for the total mortality, they are unlikely to have affected the validity of the comparison made between different zones, because there is no reason why their number should be more in one zone than in another.

When one has to depend on case records for the number of sufferers of a disease a progressive failure to retrieve records as one searches further back in time is inevitable if the period is long and, therefore, such indirect surveys invariably result in underestimates of frequency. In the present mode of inquiry there is no way of eliminating this error, but we believe that it was not great, as a preliminary estimate of the number of deaths was available to each unit from its own death certificate books. Moreover, this would not affect comparisons between different zones, the main aim of this study, as there is no reason why this bias should apply to any particular zone more than the others.

A variable degree of efficiency with which the various units had kept their records may introduce a similar bias. Another point, though unlikely, is the possibility that doctors in some zones may have 
more readily diagnosed ischæmic heart disease than others did.

As one means of testing these possibilities, the data on the central zone had been further analysed as this could provide an independent source of information. Out of 126 deaths in the central zone, 40 were among south Indians, all on Secunderabad division in the south (population 28,764 employees), giving a mortality of 139 per 100,000 in south Indians, but only 4 on the Jhansi division in the north (population 28,811), giving a death rate of $13 \cdot 8$ per 100,000 . The mortality on the Ferozepur division in north India (population 23,950) was also low, being 10.7 per 100,000 which fits in with the figure from Jhansi.

A second and perhaps more convincing test of bias can be made by comparing the morbidity rates from myocardial infarction. Morbidity was, therefore, explored by examining the hospital records of the patients diagnosed as suffering from acute myocardial infarction from a few of the representative railway hospitals on different zones (Malhotra, 1967a), which showed that there were 7 times as many cases of acute myocardial infarction in Madras (south India) as in Ferozepur (north India).

A final proof is provided by the data from two independent sources, namely the Employees' State Insurance Health Corporation (1957, 1958, and 1962) reported in part by Padmavati (1962), which pertains to non-railway industrial workers (Table $\mathrm{V}$ ), and in an indirect way by the data of Singh and Prakash (1964), from a teaching hospital in the Punjab, north India, both of which showed similar geographical trends. These extra sources of information make it improbable that the geographical differences noted by us could be due to bias in our data.

When data analysed in a number of different ways and from a number of different sources produce the same conclusion it is not unreasonable to discount errors due to bias.

Turning to Table I, we therefore see that big differences in mortality from ischæmic heart disease are present in different parts of India: deaths being 7 times more in the south as compared with the north.

\section{CoNCLUSIONS}

Physical Exercise versus Inactivity. An unexpected and extraordinary finding in our data is that mortality in the sedentary occupation of clerks is lower than the physically active occupation of fitters. Since this is contrary to the current concepts of the protective role of exercise, a number of alternative explanations must be considered. Because promotions and transfers among fitters take place within the trade, whereas a small proportion of clerks gets promoted to welfare inspectors or even to the executive grades, thus making room for new recruits in the younger age-groups, the discrepancy could be due to a dilution of the population at risk. This is, however, unlikely for two reasons: (1) such promotions and transfers are never more than 1 per cent of the total number of clerks and, therefore, this cannot account for the big differences; (2) the policy and the degree of promotion is uniform for all the railway zones and it should have affected the mortality among the clerks equally on all the zones. In fact, this is not the case, and while there were no differences between the mortality of clerks and fitters on the southern zone, big differences were present on the eastern, north-eastern, and northern regions (Table II). A less obvious but equally important factor which could produce this discrepancy is that following an attack of acute myocardial infarction, especially if there were incapacitating sequelæ, the problems of job placement may have altered a man's occupation: a man in physically strenuous work will tend to be placed in a sedentary job after his attack. In trades considered in this paper, however, the job placement is usually done within the trade itself, by giving "light" duties of a sedentary nature, for a specified period. Moreover, because this policy of job placement is uniform in all the zones, it is not likely to have made any differences in the comparison between the mortality experience of different occupations in the various zones.

What is important and even more surprising is that there are striking geographical variations in the same occupations whether sedentary or physically active: the mortality among sweepers is 15 times more in the southern zone as compared with the northern, despite there being no difference in their age distribution and the amount of physical activity of work on these two zones. Furthermore, though the sweepers and fitters are equally physically active, there are big differences in their mortality in some zones and not on others, for example, in the northern zones the mortality among fitters is 7 times more than among sweepers, whereas there were no prominent differences in the mortality between these two trades in the southern zone.

Clearly, therefore, it is difficult to reconcile our observations on the basis of the current hypothesis that "physical activity of work is a protection against ischæmic heart disease". We must, therefore, agree with Friedberg (1963) and Spain and Bradess (1960) that claims of causal relation of physical activity at work fail to exclude other possible factors.

Socio-economic Factors. The higher prevalence 
TABLE V

EMPLOYEES STATE INSURANCE DATA (Reproduced by kind permission)

Number of new cases per 1000 insured persons for arteriosclerotic and degenerative heart disease for the year 1958-59 and 1961-62

\begin{tabular}{|c|c|c|}
\hline State & $\begin{array}{c}\text { No. of new cases } \\
\text { per } 1000 \text { insured } \\
\text { persons for } 1958-59^{\star}\end{array}$ & $\begin{array}{l}\text { No. of new cases } \\
\text { per } 1000 \text { insured } \\
\text { persons for } 1961-62 t\end{array}$ \\
\hline $\begin{array}{l}\text { Punjab (PS) } \\
\text { Delhi (SS) } \\
\text { Rajasthan (SS) } \\
\text { Uttar Pradesh (SS) } \\
\text { Maharashtra (PS) } \\
\text { Maharashtra (SS) } \\
\text { West Bengal (PS) } \\
\text { Bihar } \\
\text { Madras (SS) } \\
\text { Madras (PS) } \\
\text { West Bengal (PS) } \\
\text { Mysore (SS) }\end{array}$ & $\begin{array}{l}0.24 \\
0.13 \\
0.54 \\
0.11 \\
0.41 \\
0.22 \\
0.90 \\
0.13 \\
1.66 \\
0.71 \\
0.90 \\
4 \cdot 42\end{array}$ & $\begin{array}{l}0.64 \\
0.07 \\
0.16 \\
1.15 \\
0.52 \\
0.89 \\
0.59 \\
1.32 \\
0.52 \\
1.25 \\
0.59 \\
0.44\end{array}$ \\
\hline All India & 0.63 & 0.62 \\
\hline
\end{tabular}

PS = Panel system. SS $=$ Service system.

$\star$ Reproduced from p. 171 of Annual Report of Employees State Insurance Corporation for 1958-59.

t Reproduced from p. 76 of Annual Report of Employees State Insurance Corporation for 1961-62.

of the disease amongst the executives (Table V) seems to be in keeping with the social class gradients noted in studies from different countries (Toor et al., 1957; Dreyfuss, 1953; Padmavati, 1962). But what is surprising is that the effect of this social gradient especially between our social classes III and IV was prominent in some zones and practically absent in others; for example, while the mortality among social class III was comparable with social class IV on the southern, central, western, and south-eastern zones, big differences were present on the northern, north-eastern, and eastern zones (Table III). A second and equally dependable proof of this behaviour is provided by two of our socially different but equally physically active trades: thus the mortality experience between fitters (a higher social class) and sweepers (a lower social class) showed prominent differences in some zones, whereas in others these differences were either less prominent or not present at all (Table II).

The reasons for the abnormally high mortality among the top executives are not clear but may be dietary, as big dietary differences exist between the economically well-off and the poor classes. It is, perhaps, worth mentioning at this point, that the differences in the pattern of diet and eating between various socio-economic groups are not so prominent among South Indians as in the north of the country. While boiled rice and hot lentil soups or ragi gruel are the staple diets in the south-diets which are bolted down without much chewing-in the north the social class differences in the pattern of diet and eating are much more prominent, for instance, while the lower socio-economic groups eat thick roti made of coarse wheat or other cereals, such as millet which requires thorough chewing, the higher social classes eat thin wheat chappatis of refined grains containing less roughage and fibre and requiring less masticatory effort. One factor which stands out clearly from the present data, however, is that the mean age at death for the top executives is higher as compared with the other two social classes and this higher age-group may explain their higher mortality experience. Similar reasoning seems to apply to the gradient between our social classes III and IV. These results, therefore, make it improbable that socio-economic status carrying added responsibility or a higher standard of living per se may have a causal relation. The social gradient may, on the other hand, be due to dietary differences as well as to the fact that as the socio-economic group rises the number at risk falls and the average age rises (Table IIIA and Fig. 2).

Factors of Age and Sex. The marked sex discrepancy in our data appears unusual, but if it is borne in mind that the women at risk in this group, being the wives and daughters of serving railwaymen, would not be of the vulnerable age, our data are in keeping with the general observation that women rarely have ischæmic heart disease before the menopause and usually there are special circumstances when they do (Morris, 1964). The average age at death is a decade less in the south than in the north, and this is in keeping with the observations of others (Vakil, 1949; Samani, 1956). Furthermore, the average age at death of the executives is higher than in social class III, which in turn is higher than in social class IV; and this may, as pointed out earlier, explain the social gradient noted in this study (Tables III and IIIA).

Smoking. The per capita sale of cigarettes is 8

TABLE VI

SALE OF CIGARETTES IN DIFFERENT STATES FOR 1964 (JANUARY TO DECEMBER)

\begin{tabular}{l|c|c|c}
\hline \multicolumn{1}{c|}{ State } & $\begin{array}{c}\text { Cigarettes } \\
\text { (quantity in } \\
100,000 \text { s) }\end{array}$ & $\begin{array}{c}\text { Population in } \\
1961 \text { census in } \\
100,000 \mathrm{~s}\end{array}$ & $\begin{array}{c}\text { Consumption in } \\
100,000 \mathrm{~s} \text { per } \\
100,000 \text { of } \\
\text { population }\end{array}$ \\
\hline Punjab & 2774 & 202.98 & 13.66 \\
Gujerat & 6082 & 206.21 & 29.52 \\
Delhi & 5822 & 26.44 & 224.00 \\
Rajasthan & 1314 & 201.46 & 6.54 \\
Uttar Pradesh & 7934 & 737.53 & 10.75 \\
Maharashtra & 6307 & 395.05 & 15.97 \\
Bihat & 2606 & 464.57 & 5.60 \\
Madras & 551 & 336.50 & 1.63 \\
Kerala & 405 & 168.75 & 2.40 \\
Andhra & 314 & 359.73 & 0.87 \\
Mysore & 725 & 235.47 & 3.09 \\
\hline
\end{tabular}

* Based on data kindly supplied by the Collector of Excise Bombay from a leading tobacco company. 
times more in the Punjab (north) as compared with Madras (south), though the incidence of the disease is 7 times more in Madras than in the Punjab (Table VI). Our data, therefore, do not bear out the correlation between smoking and ischæmic heart disease produced in a number of careful studies (Doll and Hill, 1956; Hammond and Horn, 1958), but since our data do not take into account other smoking habits and the habits of tobaccochewing, and because of the fallacies of applying such regional data from trade sources to a particular group, their value is correspondingly limited. Even after allowances are made for these limiting factors, there appears to be nothing to suggest cause and effect between smoking and ischæmic heart disease in the present study; and as pointed out by Hill (1965), "though there may be good evidence to support causation between smoking and atherosclerosis in published series, there may be other features that may go hand-in-hand with smoking, features that might conceivably be the real underlying cause or at least an important contributor, whether it be lack of exercise, nature of diet or other factors".

Stress and Strain. Many workers now doubt the once fashionable theory that the stress of modern life contributes to ischæmic heart disease. Our data on this are insufficient and inconclusive, as certain technical difficulties made it impossible to collect these data from all the zonal railways. The data available to us (Table IV) show there were 5 times more charge-sheets in the southern zone than in the northern, but when this parameter was examined for the various districts of the western zone there were no consistent correlations.

Hardness or Softness of Water. Hardness of water seems to have a possible protective influence (Table VII). Its mode of action, however, is not clear but presumably may be to precipitate the higher fatty acids into insoluble soaps and thus hamper their absorption.

Diet. There is much evidence that ischæmic heart disease is caused by the kind and quantity of food eaten, especially the amount of animal fat (Kinsell et al., 1952; Kinsell, 1964; Ahrens et al., 1958; Keys, 1956, 1964; and others). Our data, however, do not support this association of high fat intake with the liability to develop ischæmic heart disease, because while in the north the consumption of fats, most of which are animal fats, is 19 times more than in the south (Indian Council of Medical Research, 1964), the disease is 7 times less in the north than in the south. Moreover, while the milk fats eaten in the north have a preponderance of saturated fatty acids, the seed oils used in the south are mainly composed of unsaturated fatty acids (Indian Council of Medical Rsearch, 1963). This inverse association is noteworthy, especially because others have also observed this association of high intake of animal fats and freedom from cardiovascular disease (Shaffer et al., 1964; Shaper, Jones, and Kyobe, 1961; Mann, Shaffer, and Rich, 1965). This evidence from other studies and our additional findings of the inverse association of a low intake of total as well as animal fats and a high frequency of ischæmic heart disease in the south are contrary to the view that it is the quantity of dietary fats and their degree of saturation that bear responsibility for cases of this disease.

Lately, however, several workers have observed that it is not dietary fat but sucrose or simple carbohydrate which correlates positively with ischæmic heart disease (Cohen and Teitelbaum, 1964; Yudkin and Roddy, 1964).

\section{TABLE VII}

LOCATION OF WATER-SOFTENING PLANTS ON VARIOUS ZONAL RAILWAYS IN INDIA, SHOWING DEGREE OF PERMANENT HARDNESS IN P.P.M.

\begin{tabular}{|c|c|c|}
\hline Railway zone & Place & $\begin{array}{c}\text { Hardness of water } \\
\text { (p.p.m.) }\end{array}$ \\
\hline $\begin{array}{l}\text { Southern } \\
\text { Cen"ral } \\
\text { ", } \\
\text { ", } \\
\text { Northern } \\
\text { ", } \\
\text { North-eastern } \\
\text { ", } \\
\text { North-east frontier } \\
\text { Western } \\
\text { ", } \\
\text { ", } \\
\text { ", } \\
\text { ", } \\
\text { ", }\end{array}$ & 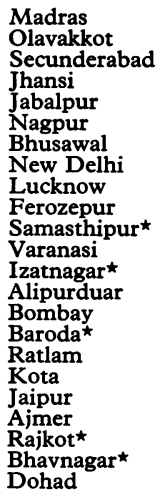 & $\begin{array}{c}99 \\
98 \\
150 \\
200 \\
30 \\
160 \\
365 \\
\text { Not available } \\
20 \\
123 \\
273 \\
\text { Not available } \\
260 \\
\text { Not available } \\
84 \\
312 \\
252 \\
88 \\
\text { Not available } \\
\text { Not available } \\
400 \\
400 \\
96\end{array}$ \\
\hline
\end{tabular}

$\star$ Places with water-softening plants.

The data on fat and sugar consumption of Indians in the north as compared with those in the south (Fig. 2), which are consistent with our own diet surveys, do not support either the fat thesis or the sugar thesis. In fact, this study shows an "inverse" association of high intake of animal fat, a high intake of sugar, and comparative freedom from ischæmic heart disease in the Punjab (north India) in contrast to a low intake of animal fat, a low intake of sugar, and a high frequency of ischæmic heart disease in the south. Furthermore, despite the 
attention given to dietary fat intake as a prominent environmental factor responsible for the increasing incidence of ischæmic heart disease, there is remarkably little evidence that a change in the nature of fat intake influences survival after the development of ischæmic heart disease (Rose, Thomson, and Williams, 1965; Research Committee: Ball et al., 1965). Obviously our data do not fit the hypothesis that low ratios of poly-unsaturated to saturated fatty acids in food, or even an excess of sugar in food, contribute to an increased incidence of ischæmic heart disease.

\section{Comments}

The big geographical differences in mortality from ischæmic heart disease in different parts of India are in keeping with studies from other parts of the world (World Health Organization, 1961), and support the thesis that environmental factors are important in the causation of this disease, most of which may be preventable. The procedural problem in all this work is the usual one encountered in epidemiological studies of chronic disease: how can we disentangle from the thicket of environmental factors those which relate with certainty to causation of ischæmic heart disease ?

Neither smoking, nor socio-economic factors, nor physical activity of work, nor even stress and strain have provided any tenable associations with the immunity from or a liability to develop ischæmic heart disease, in the data presented in this paper. Nor is there any incontrovertible evidence that the total amount of fat in the diet bears responsibility for the production of this disease. Does it mean that these factors are not important, or they are less important than some others? What are the environmental factors that are positively related to the geographical variations in the prevalence of this disease noted in this study?

While question (1) must be answered in the affirmative, it is less easy to answer question (2) on the basis of the data presented in this paper. Because of the striking differences in the dietary habits in different parts of the country, the pattern of diet and eating, perhaps, has important implications in the geographical aspects of ischæmic heart disease (Malhotra, 1967b).

Elsewhere, we have discussed in detail the striking differences in the pattern of diet and eating in different geographical regions in the country (Malhotra, 1964, 1967a) and their role in the causaion of ischæmic heart disease. It was pointed out that the methods of preparing food and of cooking produce important differences in the physical state of fats. Thus the particle size of fats in solution is greatly reduced by the culinary practices in the north as compared with those in the south. Furthermore, because of the large quantities of milk and fermented milk products used in the north, especially in the Punjab and Saurashtra, there is a preponderance of short-chain fatty acid triglycerides in the fed fats of these populations as compared with those in the south who largely consume seed oils in which the long-chain acids are prominent. There are striking differences even in the pattern of eating (Malhotra, 1964). Thus, while the south Indian foods are sloppy and do not require much chewing, the north Indian foods require long mastication and ingestion of larger amounts of saliva (Malhotra, Saigal, and Mody, 1965). The effect of the pattern of diet and eating on gall-bladder evacuation and on the amounts of bile entering the intestinal lumen has been discussed (Malhotra, 1966a). It was shown that the sloppy south Indian régimes gave rise to higher amounts of bilirubin entering the intestine as compared with the masticatory Punjabi food. Further, it was noted that if the sloppy south Indian food was masticated well, resulting in the ingestion of large amounts of saliva, the amounts of bilirubin entering the intestinal lumen fell significantly.

This has important implications on the rate as well as the route of absorption of fats because, as shown by Dawson and Saunders (1965) and Kern and Borgström (1965), these depend directly on the amount of bilirubin in the intestine, and also because short-chain fatty acid triglycerides get absorbed "directly", as do those which are finely emulsified, whereas long-chain fatty acid triglycerides and non-emulsified fats have an absolute dependance upon the presence of bile for their digestion and absorption, and they are then reconverted into complex fatty acid triglycerides whose nature is partly a species characteristic. (For several references on this subject see Davson, 1964, and Davidson and Passmore, 1963.) Since, in feeding experiments, the triglyceride acids approached the fatty acid composition of fed fats (Ahrens et al., 1958), it is reasonable to conclude that the effect of the differences in the fatty acid composition of the diets of south Indians versus north Indians combined with the differences in the bile flow-rates in them, would give rise to a preponderance of shortchain fatty acids in the plasma of Indians in the north as compared with those in the south (Malhotra, 1967a). Connor and Poole (1961) and Connor, Hoak, and Warner (1963) have found in experimental systems that thrombosis is facilitated by long-chain saturated fatty acids, e.g. fatty acids with not less than 16 carbon atoms enhanced thrombosis, but short-chain $\left(\mathrm{C}_{6}-\mathrm{C}_{7}\right)$ saturated fatty acids 
produced virtually no enhancement. Similarly Boyles (1959) has shown that the particle size of fat in solution influences blood coagulation.

Differences in the pattern of diet and eating appear, therefore, to have important biological significance with regard to the epidemiological differences in the occurrence rates of ischæmic heart disease noted in this study, and these may be mediated through their effect on the dynamic equilibrium between blood coagulation and fibrinolytic enzyme systems as discussed more fully elsewhere (Malhotra, 1966b, c, 1967a, b).

\section{SUMMARY}

Mortality trends from arteriosclerosis including coronary heart disease have been explored retrospectively in railway populations in India. Big geographical differences between areas were present, the disease being 7 times more common in the south as compared with the north. In addition to strong dietary differences, there were intriguing geographical variations between sedentary versus physically active occupations on the one hand, and different socio-economic groups on the other. The current hypothesis of diet, the decline of physical activity, and smoking and stress does not find support in this study. The possible part played by diet has been discussed elsewhere (Malhotra, 1967a, 1966a), which seems to indicate that the relative proportions in the diet of short-chain versus the complex long-chain fatty acids, triglycerides, and the particle size of the food fats, may be reflected in the plasma triglycerides, and may determine the dynamic equilibrium between blood coagulation and fibrinolysis.

\section{REFERENCES}

Ahrens, E. H., Jr., Hirsch, J., Insull, W., Jr., and Peterson, M. L. (1958). Dietary fats and human serum lipid levels. In Chemistry of Lipids as Related to Atherosclerosis, ed. I. H. Page, pp. 222-261. C. C. Thomas, Springfield, Illinois.

Boyles, P. W. (1959). Particle size as a factor in thromboplastin formation. Blood, 14, 1063.

Cohen, A. M., and Teitelbaum, A. (1964). Effect of dietary sucrose and starch on oral glucose tolerance and insulinlike activity. Amer. F. Physiol., 206, 105.

Connor, W. E., Hoak, J. C., and Warner, E. A. (1963). Massive thrombosis produced by fatty acid infusion. F. clin. Invest., 42, 860 .

- , and Poole, J. C. F. (1961). The effect of fatty acids on the formation of thrombi. Quart. F. exp. Physiol., 46, 1 .

Davidson, S., and Passmore, R. (1963). Human Nutrition and Dietetics, 2nd ed., pp. 97-99. Livingstone, Edinburgh and London.
Davson, H. (1964). A Textbook of General Physiology, 3rd ed., p. 525 . Churchill, London.

Dawson, A. M., and Saunders, D. R. (1965). The effect of bile salts on the pathway of fat absorption in the rat. In The Biliary System, A Symposium of the NATO Advanced Study Institute, ed. W. Taylor, pp. 184-186. Blackwell, Oxford.

Doll, R., and Hill, A. B. (1956). Lung cancer and other causes of death in relation to smoking-A second report on mortality of British doctors. Brit. med. F., 2, 1071.

Dreyfuss, F. (1953). The incidence of myocardial infarctions in various communities in Israel. Amer. Heart f., 45, 749.

Employees' State Insurance Health Corporation. Annual reports for 1957, 1958, and 1962. Department of Social Security, Govt. of India, New Delhi.

Friedberg, C. K. (1963). Physical effect of the emotions in the genesis of coronary occlusion and myocardial infarction. In Henry Ford Hospital International Symposium, The Aetiology of Myocardial Infarction, ed. T. N. James and J. W. Keyes, p. 427. Little, Brown, Boston; Churchill, London.

Hammarsten, J. F., Cathey, C. W., Redmond, R. F., and Wolf, S. (1957). Strum cholesterol, diet and stress in patients with coronary artery disease. (Abstract.) F. clin. Invest., 36, 897.

Hammond, E. C., and Horn, D. (1958). Smoking and death rates-Report on forty-four months of follow-up of 187,783 men. II. Death rates by cause. F. Amer. med. Ass., 166, 1294.

Hill, A. B. (1965). The environment and disease: association or causation? Proc. roy. Soc. Med., 58, 295.

Indian Council of Medical Research (1953). Diet surveys in India. Sp. Rep. Ser. No. 25.

- (1963). Nutritive value of Indian foods. Sp. Rep. Ser. No. 42.

- (1964). Diet atlas of India. Sp. Rep. Ser. No. 48.

Kern, F., Jr., and Borgström, B. (1965). The effect of a conjugated bile salt on oleic acid absorption in the rat. Gastroenterology, 49, 623.

Keys, A. (1956). The diet and the development of coronary heart disease. F. chron. Dis., 4, 364.

(1964). Epidemiological aspects of atherosclerosis and the diet. Geriatrics, 19, 542.

Kinsell, L. W. (1964). The importance of polyunsaturated fats. Geriatrics, 19, 551.

—, Partridge, J., Boling, L., Margen, S., and Michaels, G. (1952). Dietary modification of serum cholesterol and phospholipid levels. F. clin. Endocr., 12, 909.

Malhotra, S. L. (1964). Peptic ulcer in India and its ætiology. Gut, 5, 412.

- (1966a). Effect of diet and antacids on gall-bladder emptying. Abst. in Proc. 3rd Wld Congr. Gastroenterol., Tokyo, fapan, pp. 2-106.

- (1966b). Causal influences in ischæmic heart disease in India. (Abstract.) f. Ass. Phycns India, 14, 543.

(1966c). The phenomenon of clot-lysis. F. Ass. Phycns India, 14, 543.

- (1967a). Geographical aspects of acute myocardial infarction in India with special reference to the pattern of diet and eating. Brit. Heart f., 29, 337.

- (1967b). Serum lipids, dietary factors and ischæmic heart disease in India. (Abstract.) f. Ass. Phycns India, 14, 93.

-, Saigal, O. N., and Mody, G. D. (1965). Role of saliva in the ætiology of peptic ulcer. Brit. med. F., 1, 1220.

Mann, G. V., Shaffer, R. D., and Rich, A. (1965). Physical fitness and immunity to heart disease in Masai. Lancet, 2, 1308. 
Morris, J. N. (1964). Uses of Epidemiology, p. 174 . Livingstone, Edinburgh and London.

- , Heady, J. A., Raffle, P. A. B., Roberts, C. G., and Parks, J. W. (1953). Coronary heart disease and physical activity of work. Lancet, 2, 1053, 1111.

Padmavati, S. (1962). Epidemiology of cardiovascular disease in India. II. Ischemic heart disease. Circulation, 25, 711 .

Research Committee (1965). Ball, K. P., Hanington, E., McAllen, P. M., Pilkington, T. R. E., Richards, J. M., Sharland, D. E., Sowry, S. C., and Wilkinson, P. Lowfat diet in myocardial infarction. A controlled trial. Lancet, 2, 501.

Rose, G. A., Thomson, W. B., and Williams, R. T. (1965). Corn oil in treatment of ischæmic heart disease. Brit. med. F., $1,1531$.

Samani, O. T. (1956). Coronary heart disease in low income population in India. Indian Heart f., 8, 104

Schroeder, H. A. (1960). Relation between mortality from cardiovascular disease and treated water supplies. $\mathcal{F}$. Amer. med. Ass., 172, 1902.

Shaffer, R. D., Mann, G. V., Anderson, R. S., and Sandstead, H. H. (1964). Heart disease among the milk-and-meat- eating Masai of Tanganyika. In Proc. 6th Int. Congr. Nutr., Edinburgh, 1963, p. 616. Livingstone, Edinburgh and London.

Shaper, A. G., Jones, M., and Kyobe, J. (1961). Plasmalipids in an African tribe living on a diet of milk and meat. Lancet, 2, 1324.

Singh, A., and Prakash, C. (1964). Incidence of ischæmic heart disease in the Punjab. In Proceedings of the International Seminar on Arteriosclerosis, ed. K. K. Datey, I. S. Pinto, and P. E. Bharucha, pp. 7-11. Asia Publishing House, Bombay.

Spain, D. M., and Bradess, V. A. (1960). Occupational physical activity and the degree of coronary atherosclerosis in "normal" men. Circulation, 22, 239.

Toor, M., Katchalsky, A., Agmon, J., and Allalouf, D. (1957). Serum-lipids and atherosclerosis among Yemenite immigrants in Israel. Lancet, 1, 1270.

Vakil, R. J. (1949). A study of coronary heart disease in India. Indian Heart $\mathcal{F}$., 1, 201.

World Health Organization (1961). Epidem. vital Statist. Rep., 14, 291.

Yudkin, J., and Roddy, J. (1964). Levels of dietary sucrose in patients with occlusive atherosclerotic disease. Lancet, 2, 6. 